\title{
DNA and wine
}

\author{
Shaun R. McCann ${ }^{1}$
}

Received: 11 November 2019 / Revised: 14 November 2019 / Accepted: 14 November 2019 / Published online: 26 November 2019

(c) Springer Nature Limited 2019

'Wine makes every meal an occasion, every table more elegant, every day more civilized'.

André Simon. French wine merchant, gourmet and wine writer (1877-1970).

DNA analyses help to pick a donor and are also useful for wine provenance.

In 1953 Watson and Crick (Fig. 1), building on Rosalind Frankland's X-ray diffraction studies of DNA, published their seminal paper on the double helix [1]. This discovery lead to the possibility that diseases could be understood at a molecular level and opened the way for the development of new cures. They were both influenced by Erwin Schrödinger's book 'What is life?' Sickle Cell Disease (SCD) has been called the 'first molecular disease' and is known to result from a single amino acid substitution but as yet we do not have a widely acceptable, effective and inexpensive treatment for this devastating condition. The culmination of the 'Human Genome Project' in 2001 held the promise of great advances but even its staunchest supporters would agree that the impact on medicine has, so far, been disappointing.

Many allogeneic haematopoietic cell transplants (HCT) took place between the mid-1950s and 1970s with a very poor outcome as documented by Bortin [2]. The understanding of the importance of the HLA system in HCT and technological advances for elucidating the HLA system have contributed to the outcome of HCT. The outcome of HCT largely depends on the matching between the donor and recipient for HLA antigens which are encoded on the short arm of chromosome 6 called the major histocompatibility complex. The HLA system is highly polymorphic and was originally determined using Terasaki plates which

Shaun R. McCann

shaunrmccann@gmail.com

Emeritus Haematology Trinity College, Dublin, Ireland could detect A, B, C and DR by complement dependent microlymphotoxicity using human antibodies derived from alloimmunized donors.

More modern and specific tests include a number of PCR (polymerase chain reaction) based technologies such as the use of sequence-specific primers (PCR-SSPs), sequencespecific oligonucleotides (PCR-SSOs) and sequence-based typing. Sanger sequencing was the most accurate method available but so-called Next-Generation Sequencing (NGS) offers the highest level of resolution [3]. DNA-based technology also helps in picking so-called 'permitted' mismatches for unrelated transplants and the use of cord blood as a source of haemopoietic cells.

Is DNA-based technology used in the wine industry? Yes. Ampelographers (people who identify and classify vines) traditionally used the morphology of vine leaves to determine a wine's provenance (Fig. 2). Although this may seem a little arcane to some it became very important in the 19th century with the importation of diseases such as phylloxera [4] into Europe. The ability to identify vines which had the greatest resistance to infectious agents were used for vine breeding and as rootstocks. More recently DNA-based technologies have become widely used. DNA fingerprinting was first used in cultivars (grape varieties that been selectively cultivated) in 1993 [5]. The technology relies on the amplification of highly polymorphic microsatellites and Meredith and Bowers in 1997 demonstrated that Cabernet Sauvignon was in fact a cross (probably spontaneous) between Cabernet Franc and Sauvignon Blanc. Single nucleotide polymorphisms (SNPs) may also prove useful as they are abundant in the genome, genetically stable and suited to high output detection platforms. However, a note of caution should be added as Catalano and colleagues had difficulty in authenticating some wines using this technology [6]. Grape DNA loss may occur during fermentation and stabilization.

An area which is probably more interesting to wine drinkers is the detection of fraud. Probably the best-known case of wine fraud was when William Koch purchased wine, he believed was from Thomas Jefferson's collection. 


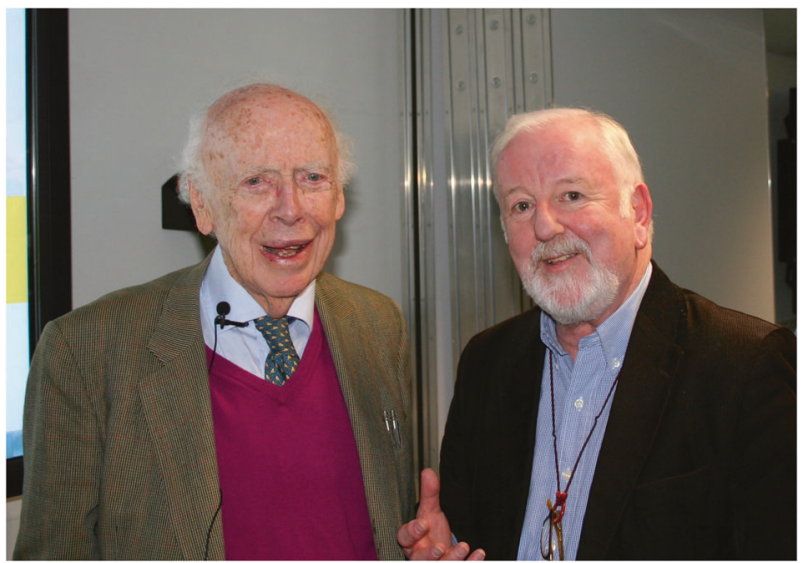

Fig. 1 James Watson and author Shaun McCann in Trinity College Dublin

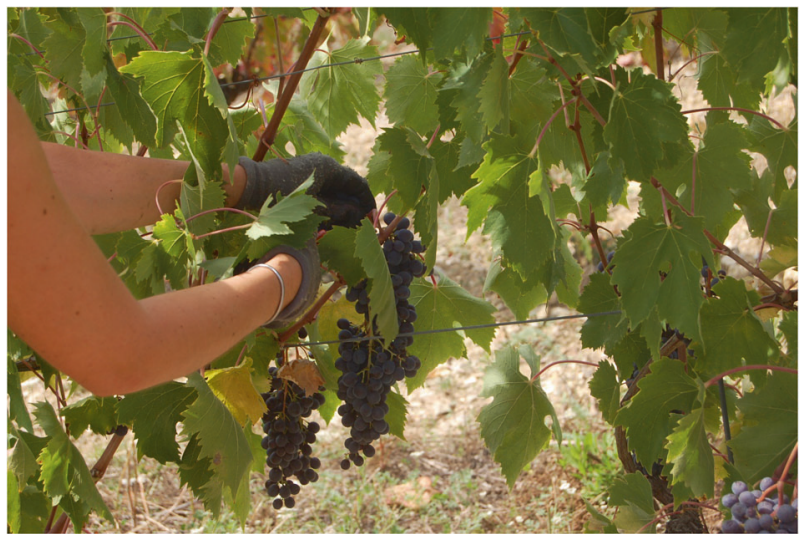

Fig. 2 Hand-harvesting Sangiovese grapes. Large 3-lobed leaves with triangular apical lobes

It was not. He successfully sued the wine dealer Eric Greenberg and was awarded $\$ 12$ million in a US district court. The use of grapes other than those mentioned on the label or associated with a certain area or grape variety was probably fairly common in the 18th and 19th centuries. In their book 'Chianti Classico: the search for Tuscany's Noblest Wines', Bill Nesto [7] and colleagues state that 'in 1830...it was impossible for real Chianti to distinguish itself from the mass of mediocre Tuscan wine in the export market'. Happily, the situation now is much better thanks to the Ricasoli and Antinori families. There are now many excellent wine makers in Tuscany. Perhaps a good philosophy is to check the history of the vintage with the current owners, buy through a reputable importer and do not spend more than you can afford to lose. Most of us probably do not need to engage in DNA-based wine technology.

As in medicine, trust is so important and I have many friends who make wine and trust them not to engage in fraud.

Acknowledgements I wish to thank Dr Emer Lawlor for her helpful comments.

\section{Compliance with ethical standards}

Conflict of interest The author declares that he has no conflict of interest.

Publisher's note Springer Nature remains neutral with regard to jurisdictional claims in published maps and institutional affiliations.

\section{References}

1. Watson JD, Crick F. A structure for deoxyribose nucleic acid. Nature. 1953;171:737-8.

2. Bortin MM. A compendium of reported bone marrow transplants. Transplantation. 1970;9:571-87.

3. Spierings S, Fleischhauer K, Carreras E, Dufour C, Mohty M, Kröger N, editors. The EBMT handbook. Hematopoietic stem cell transplantation and cellular therapies. Chapter 9. Fondation José Carreras, Switzerland: Springer Nature; 2019. ISBN 978-3-030-02277-8.

4. McCann S. Patients get viral infections: so, do vines. Bone Marrow Transplant. 2019. https://doi.org/10.1038/s41409-019-0719-6.

5. Robinson J, Harding J. The Oxford companion to wine. 4th ed. UK: Oxford University Press; 2015.

6. Catalano V, Moreno Sanz P, Lorenzi S, Grando MS. Experimental review of DNA-based methods for wine traceability and development of a single nucleotide polymorphism (SNP) genotyping assay for quantitative varietal authentication. J Agric Food Chem. 2016; 64:6969-84.

7. Nestor WR, Di Savino F. Chianti Classico: the search for Tuscany's noblest wines. Oakland, CA: University of California Press; 2016. ISBN 978-0-520-28442-5. 